\title{
The Argasidae, Ixodidae and Nuttalliellidae (Acari: Ixodida) of the world: a list of valid species names
}

\author{
ALBERTO A. GUGLIELMONE ${ }^{1,8}$, RICHARD G. ROBBINS ${ }^{2}$, DMITRY A. APANASKEVICH ${ }^{3}$, \\ TREVOR N. PETNEY ${ }^{4}$, AGUSTÍN ESTRADA-PEÑA ${ }^{5}$, IVAN G. HORAK ${ }^{6}$, \\ RENFU SHAO ${ }^{7} \&$ STEPHEN C. BARKER $^{7}$ \\ ${ }^{1}$ Instituto Nacional de Tecnología Agropecuaria, Estación Experimental Agropecuaria Rafaela, Argentina \\ ${ }_{2}^{2}$ ISD/AFPMB, Walter Reed Army Medical Center, Washington, DC 20307-5001, USA. E-mail: richard.robbins@osd.mil \\ ${ }^{3}$ U. S. National Tick Collection, the James H. Oliver, Jr. Institute of Arthropodology and Parasitology, Georgia Southern University, \\ Statesboro, Georgia 30460-8056, U.S.A. E-mail: dapanaskevich@georgiasouthern.edu \\ ${ }^{4}$ Zoologisches Institut I, Abteilung für Ökologie und Parasitologie, Kornblumenstrasse 13, 76131 Karlsruhe, Germany. \\ E-mail: Trevor.petney@t-online.de \\ ${ }^{5}$ Universidad de Zaragoza, Facultad de Veterinaria, Miguel Servet 177, CP 50013, Zaragoza, Spain. E-mail: aestrada@unizar.es \\ ${ }^{6}$ Department of Veterinary Tropical Diseases, Faculty of Veterinary Science, University of Pretoria, Onderstepoort, 0110 South Africa. \\ E-mail:ivan.horak@up.ac.za \\ ${ }^{7}$ Parasitology Section, School of Molecular and Microbiological Sciences, University of Queensland, Brisbane, Queensland 4072, \\ Australia.E-mail: s.barker@uq.edu.au \\ ${ }^{8}$ Corresponding author. E-mail: aguglielmone@rafaela.inta.gov.ar
}

\begin{abstract}
This work is intended as a consensus list of valid tick names, following recent revisionary studies, wherein we recognize 896 species of ticks in 3 families. The Nuttalliellidae is monotypic, containing the single entity Nuttalliella namaqua. The Argasidae consists of 193 species, but there is widespread disagreement concerning the genera in this family, and fully 133 argasids will have to be further studied before any consensus can be reached on the issue of genus-level classification. The Ixodidae comprises 702 species in 14 genera: Amblyomma (130 species, of which 17 were formerly included in Aponomma, a genus that is still considered valid by some authors), Anomalohimalaya (3), Bothriocroton (7, all previously included in Aponomma), Cosmiomma (1), Cornupalpatum (1), Compluriscutula (1), Dermacentor (34, including the single member of the former genus Anocentor, which is still considered valid by some authors), Haemaphysalis (166), Hyalomma (27), Ixodes (243), Margaropus (3), Nosomma (2), Rhipicentor (2) and Rhipicephalus (82, including 5 species from the former genus Boophilus, which is still considered valid by some authors). We regard six names as invalid: Amblyomma laticaudae Warburton, 1933 is a synonym of Amblyomma nitidum Hirst \& Hirst, 1910; Bothriocroton decorosum (Koch, 1867) is a synonym of B. undatum (Fabricius, 1775); Haemaphysalis vietnamensis Hoogstraal \& Wilson, 1966 is a synonym of H. colasbelcouri (Santos Dias, 1958); Haemaphysalis xinjiangensis Teng, 1980 is a synonym of $H$. danieli Černý \& Hoogstraal, 1977; Hyalomma erythraeum Tonelli-Rondelli, 1932 is a synonym of H. impeltatum Schulze and Schlottke, 1930 and Rhipicephalus hoogstraali Kolonin, 2009 was not described according to the rules of the International Code of Zoological Nomenclature.
\end{abstract}

Key words: Acari, Argasidae, Ixodidae, Nuttalliellidae, species list

\section{Introduction}

Over the last decade, tick (Acari: Ixodida) systematics has undergone a remarkable—and contentious revolution. Between 1998 and 2008 three comprehensive lists of supposedly valid tick names were published by Camicas et al. (1998), Horak et al. (2002) and Barker and Murrell (2008). Additionally, Kolonin (2009) compiled a list of world Ixodidae, while Guglielmone et al. (2009) addressed controversial tick names. With the exception of Camicas et al. (1998), the preceding studies rely heavily on the compilations of Keirans 
(1992) and Keirans and Robbins (1999). All these works disagree with one another to a greater or lesser extent. Consequently, we have attempted to combine their best elements with our own original research to develop a new global list of tick species names that are valid as of late 2009.

There are several competing genus-level classifications of the Ixodidae in Camicas and Morel (1977), Hoogstraal and Aeschlimann (1982), Black and Piesman (1994), Filippova (1994), Camicas et al. (1998), Barker and Murrell (2002) and Horak et al. (2002). Disagreements at the genus level often concern particular species groups. For example, some authorities continue to regard Boophilus as a valid genus, although most recent authors have relegated this group of five species to a subgenus of Rhipicephalus. Similarly, Aponomma is viewed as a valid genus by many taxonomists, but recent workers have moved some species to the genus Bothriocroton (the former "Australian Aponomma species") and placed the remainder in Amblyomma. The genus Anocentor remains valid in some genus-level classifications, but most workers consider this monotypic genus to be, at best, a subgenus of Dermacentor. The greatest differences of opinion concern the largest ixodid genus-Ixodes-whose species have been dispersed into several genera (Ceratixodes, Eschatocephalus, Ixodes, Lepidixodes, Pholeoixodes, Scaphixodes) by Camicas and Morel (1977) and Camicas et al. (1998). However, this arrangement has been widely resisted and will not be further considered here.

The tumult in tick taxonomy has yielded competing genus-level classifications of the Argasidae that are vastly different from one another: Clifford et al. (1964) (Antricola, Argas, Ornithodoros and Otobius), Filippova (1966) (Alveonasus, Antricola, Argas, Ornithodoros and Otobius), Pospelova-Shtrom (1969) (Alveonasus, Antricola, Argas, Carios, Ornithodoros and Otobius), Camicas and Morel (1977) (Alectorobius, Alveonasus, Antricola, Argas, Carios, Nothoaspis, Ogadenus, Ornithodoros, Otobius and Parantricola), Hoogstraal (1985) (Antricola, Argas, Nothoaspis, Ornithodoros and Otobius), Klompen and Oliver (1993) (Argas, Carios, Ornithodoros and Otobius) and Camicas et al. (1998) (ibid. Camicas and Morel 1977 plus Microargas). Keirans (2009) retains the subgeneric classification proposed by Hoogstraal (1985). A recent molecular analysis did not settle these ongoing disputes because several alleged natural groups were poorly represented (Nava et al. 2009b). However, it appears that the genus Ornithodoros, as understood by Clifford et al. (1964) and Hoogstraal (1985), is not monophyletic, endorsing similar results from Klompen and Oliver (1993), whose study is especially relevant for its application of cladistic methods to demonstrate the paraphyly of the genus Ornithodoros, but which fails to acknowledge the contributions of Camicas and Morel (1977), further developed in Camicas et al. (1998), in considering the paraphyly of Ornithodoros as defined by the "American School". As discussed in a recent study by Estrada-Peña et al. (2010), the genus-level classification of the family Argasidae is obviously much less settled than that of the Ixodidae. Indeed, most species of Argasidae can be assigned to more than one genus-there is currently no agreement on generic placement for 133 of the 193 argasid species. It will be difficult to resolve the genera of Argasidae without additional morphological and molecular studies of the type species of putatively monophyletic groups, which are vital to an understanding of argasid phylogeny (evolutionary history). Consequently, we have focused our efforts on constructing a list of valid species names in which differences in generic assignation are noted, with the hope that this information will stimulate further phylogenetic research.

The authors of the present compilation disagree on the systematic status of several tick genera, but we share a concern about the validity of species names. We have therefore adopted, but do not necessarily endorse, the genus-level classification of the Argasidae proposed by Hoogstraal (1985) (Antricola, Argas, Nothoaspis, Ornithodoros and Otobius), and the genus-level classification of the Ixodidae embraced by Barker and Murrell (2002) (Amblyomma, Anomalohimalaya, Bothriocroton, Cosmiomma, Dermacentor, Haemaphysalis, Hyalomma, Ixodes, Margaropus, Nosomma, Rhipicentor and Rhipicephalus). In addition, we have included the fossil genera Cornupalpatum and Compluriscutula and their species. Alongside the author of each species name we have inserted, in parentheses, the names of those genera in which the species may have been placed by other workers. The type species of the various genera of Argasidae and Ixodidae are also indicated. Where appropriate, we have included comments on particular species names. Finally, six ixodid tick names that we consider invalid are discussed immediately above the list of Ixodidae. 


\section{Argasidae}

1. Antricola armasi de la Cruz and Estrada-Peña, 1995 (Carios)

2. Antricola centralis de la Cruz and Estrada-Peña, 1995 (Carios)

3. Antricola cernyi de la Cruz, 1978 (Carios)

4. Antricola coprophilus (McIntosh, 1935) (Carios). This is the type species of the genus Antricola; it was originally named Ornithodoros coprophilus.

5. Antricola delacruzi Estrada-Peña, Barros-Battesti and Venzal, 2004 (Carios)

6. Antricola granasi de la Cruz, 1973 (Carios)

7. Antricola guglielmonei Estrada-Peña, Barros-Battesti and Venzal, 2004 (Carios)

8. Antricola habanensis de la Cruz, 1976 (Carios)

9. Antricola hummelincki de la Cruz and Estrada-Peña, 1995 (Carios)

10. Antricola inexpectata Estrada-Peña, Barros-Battesti and Venzal, 2004 (Carios)

11. Antricola marginatus (Banks, 1910) (Carios, Parantricola). This is the type species of the genus Parantricola; it was originally named Ornithodoros marginatus.

12. Antricola martelorum de la Cruz, 1978 (Carios)

13. Antricola mexicanus Hoffmann, 1958 (Carios). Some authors have listed the year 1958 for the original description of Antricola mexicanus while others have used the year 1959. An inquiry to the U.S. Library of Congress has shown that Hoffmann (1958) was actually published in 1958.

14. Antricola naomiae de la Cruz, 1978 (Carios)

15. Antricola occidentalis de la Cruz, 1978 (Carios)

16. Antricola siboneyi de la Cruz and Estrada-Peña, 1995 (Carios)

17. Antricola silvai Černý, 1967 (Carios)

1. Argas abdussalami Hoogstraal and McCarthy, 1965

2. Argas africolumbae Hoogstraal, Kaiser, Walker, Ledger, Converse and Rice, 1975

3. Argas arboreus Kaiser, Hoogstraal and Kohls, 1964

4. Argas assimilis Teng and Song, 1983

5. Argas australiensis Kohls and Hoogstraal, 1962 (Carios)

6. Argas beijingensis Teng, 1983

7. Argas beklemischevi Pospelova-Shtrom, Vasil'yeva and Semashko, 1963

8. Argas boueti Roubaud and Colas-Belcour, 1933 (Carios)

9. Argas brevipes Banks, 1908

10. Argas brumpti Neumann, 1907 (Ogadenus). This is the type species of the genus Ogadenus.

11. Argas bureschi Dryenski, 1957

12. Argas ceylonensis Hoogstraal and Kaiser, 1968 (Carios)

13. Argas confusus Hoogstraal, 1955 (Carios)

14. Argas cooleyi Kohls and Hoogstraal, 1960. If Ornithodoros cooleyi McIvor, 1941 belongs to Argas, it has priority here.

15. Argas cordiformis Hoogstraal and Kohls, 1967 (Carios)

16. Argas cucumerinus Neumann, 1901

17. Argas dalei Clifford, Keirans, Hoogstraal and Corwin, 1976

18. Argas daviesi Kaiser and Hoogstraal, 1973 (Carios)

19. Argas delicatus Neumann, 1910. This species is very close to A. vulgaris, as discussed in Guglielmone et al. (2009). We consider both names valid until the types can be compared.

20. Argas dewae Kaiser and Hoogstraal, 1974 (Carios)

21. Argas dulus Keirans, Clifford and Capriles, 1971

22. Argas echinops Hoogstraal, Uilenberg and Blanc, 1967 (Ogadenus)

23. Argas falco Kaiser and Hoogstraal, 1974

24. Argas giganteus Kohls and Clifford, 1968 
25. Argas gilcolladoi Estrada-Peña, Lucientes and Sánchez, 1987

26. Argas hermanni Audouin, 1826

27. Argas himalayensis Hoogstraal and Kaiser, 1973

28. Argas hoogstraali Morel and Vassiliades, 1965 (Ogadenus)

29. Argas japonicus Yamaguti, Clifford and Tipton, 1968

30. Argas keiransi Estrada-Peña, Venzal and González-Acuña, 2003

31. Argas lagenoplastis Froggatt, 1906

32. Argas latus Filippova, 1961

33. Argas lowryae Kaiser and Hoogstraal, 1975

34. Argas macrodermae Hoogstraal, Moorhouse, Wolf and Wassef, 1977 (Carios)

35. Argas macrostigmatus Filippova, 1961

36. Argas magnus Neumann, 1896

37. Argas miniatus Koch, 1844

38. Argas monachus Keirans, Radovsky and Clifford, 1973

39. Argas monolakensis Schwan, Corwin and Brown, 1992

40. Argas moreli Keirans, Hoogstraal and Clifford, 1979

41. Argas neghmei Kohls and Hoogstraal, 1961

42. Argas nullarborensis Hoogstraal and Kaiser, 1973

43. Argas persicus (Oken, 1818)

44. Argas polonicus Siuda, Hoogstraal, Clifford and Wassef, 1979

45. Argas pusillus Kohls, 1950 (Carios)

46. Argas radiatus Railliet, 1893

47. Argas reflexus (Fabricius, 1794). This is the type species of the genus Argas; it was originally named Acarus reflexus.

48. Argas ricei Hoogstraal, Kaiser, Clifford and Keirans, 1975

49. Argas robertsi Hoogstraal, Kaiser and Kohls, 1968

50. Argas sanchezi Dugès, 1887

51. Argas sinensis Jeu and Zhu, 1982 (Carios)

52. Argas streptopelia Kaiser, Hoogstraal and Horner, 1970

53. Argas striatus Bedford, 1932

54. Argas theilerae Hoogstraal and Kaiser, 1970

55. Argas transgariepinus White, 1846 (Ogadenus)

56. Argas transversus Banks, 1902 (Microargas, Ornithodoros). This is the type species of the genus Microargas; it was originally named Argas transversa.

57. Argas tridentatus Filippova, 1961

58. Argas vespertilionis (Latreille, 1796) (Carios). This is the type species of the genus Carios; it was originally named Carios vespertilionis. Camicas et al. (1998) and Barker and Murrell (2008) consider Argas/ Carios fischeri Audouin, 1826 a valid name, while Guglielmone et al. (2009) follow Hoogstraal (1958) and Filippova (1964) in considering this name a provisional synonym of A. vespertilionis.

59. Argas vulgaris Filippova, 1961. See A. delicatus.

60. Argas walkerae Kaiser and Hoogstraal, 1969

61. Argas zumpti Hoogstraal, Kaiser and Kohls, 1968

1. Nothoaspis reddelli Keirans and Clifford, 1975 (Carios). This is the type species of the genus Nothoaspis.

1. Ornithodoros acinus Whittick, 1938 (Alveonasus, Argas)

2. Ornithodoros alactagalis Issaakjan, 1936 (Alectorobius)

3. Ornithodoros amblus Chamberlin, 1920 (Alectorobius, Carios)

4. Ornithodoros antiquus Poinar, 1995. Fossil. 
5. Ornithodoros apertus Walton, 1962

6. Ornithodoros aragaoi Fonseca, 1960 (Alectorobius, Carios). We consider this name to be provisionally valid, pending type comparison with $O$. rudis (Guglielmone et al. 2009).

7. Ornithodoros arenicolous Hoogstraal, 1953 (Alectorobius)

8. Ornithodoros asperus Warburton, 1918 (Alectorobius). See O. verrucosus.

9. Ornithodoros azteci Matheson, 1935 (Alectorobius, Carios)

10. Ornithodoros batuensis Hirst, 1929 (Alectorobius, Carios)

11. Ornithodoros brasiliensis Aragão, 1923 (Alectorobius)

12. Ornithodoros brodyi Matheson, 1935 (Alectorobius, Carios)

13. Ornithodoros camicasi (Sylla, Cornet and Marchand, 1997) (Alectorobius, Carios)

14. Ornithodoros canestrinii (Birula, 1895) (Argas, Alveonasus)

15. Ornithodoros capensis Neumann, 1901 (Alectorobius, Carios)

16. Ornithodoros casebeeri Jones and Clifford, 1972 (Alectorobius, Carios)

17. Ornithodoros cheikhi Vermeil, Marjolet and Vermeil, 1997 (Alectorobius, Carios)

18. Ornithodoros chironectes Jones and Clifford, 1972 (Alectorobius, Carios)

19. Ornithodoros chiropterphila Dhanda and Rajagopalan, 1971 (Alectorobius, Carios)

20. Ornithodoros cholodkovskyi Pavlovsky, 1930 (Alectorobius)

21. Ornithodoros clarki Jones and Clifford, 1972 (Carios)

22. Ornithodoros collocaliae Hoogstraal, Kadarsan, Kaiser and Van Peenen, 1974 (Alectorobius, Carios)

23. Ornithodoros compactus Walton, 1962

24. Ornithodoros concanensis Cooley and Kohls, 1941 (Alectorobius, Carios)

25. Ornithodoros coniceps (Canestrini, 1890) (Alectorobius, Carios)

26. Ornithodoros cooleyi McIvor, 1941 (Alveonasus, Argas). If this species belongs to Argas, it has priority over A. cooleyi Kohls and Hoogstraal, 1960.

27. Ornithodoros coriaceus Koch, 1844

28. Ornithodoros cyclurae de la Cruz, 1984 (Alectorobius, Carios)

29. Ornithodoros darwini Kohls, Clifford and Hoogstraal, 1969 (Alectorobius, Carios)

30. Ornithodoros delanoei Roubaud and Colas-Belcour, 1931 (Alveonasus, Argas)

31. Ornithodoros denmarki Kohls, Sonenshine and Clifford, 1965 (Alectorobius, Carios)

32. Ornithodoros dugesi Mazzotti, 1943 (Alectorobius, Carios). We consider this name to be provisionally valid (Guglielmone et al. 2009), although it is generally regarded as a synonym of $O$. talaje.

33. Ornithodoros dusbabeki Černý, 1967 (Alectorobius, Carios)

34. Ornithodoros dyeri Cooley and Kohls, 1940 (Alectorobius, Carios)

35. Ornithodoros eboris Theiler, 1959 (Alveonasus, Argas)

36. Ornithodoros echimys Kohls, Clifford and Jones, 1969 (Alectorobius, Carios)

37. Ornithodoros elongatus Kohls, Sonenshine and Clifford, 1965 (Alectorobius, Carios)

38. Ornithodoros eptesicus Kohls, Clifford and Jones, 1969 (Alectorobius, Carios)

39. Ornithodoros eremicus Cooley and Kohls, 1941

40. Ornithodoros erraticus (Lucas, 1849) (Alectorobius)

41. Ornithodoros faini Hoogstraal, 1960 (Alectorobius, Carios)

42. Ornithodoros foleyi Parrot, 1928 (Alveonasus, Argas)

43. Ornithodoros fonsecai (Labruna and Venzal, 2009) (n. syn.) (Alectorobius, Carios). This species was recently described by Labruna and Venzal (2009), who placed it in the genus Carios. However, its morphology indicates that it should be included as a member of Ornithodoros (as in this classification) or Alectorobius.

44. Ornithodoros furcosus Neumann, 1908 (Alectorobius)

45. Ornithodoros galapagensis Kohls, Clifford and Hoogstraal, 1969 (Alectorobius, Carios)

46. Ornithodoros graingeri Heisch and Guggisberg, 1953 (Alectorobius)

47. Ornithodoros grenieri Klein, 1965 (Alectorobius)

48. Ornithodoros gurneyi Warburton, 1926 
49. Ornithodoros hadiae (Klompen, Keirans and Durden, 1995) (Alectorobius, Carios)

50. Ornithodoros hasei (Schulze, 1935) (Alectorobius, Carios)

51. Ornithodoros hermsi Wheeler, Herms and Meyer, 1935 (Alectorobius)

52. Ornithodoros indica Rau and Rao, 1971

53. Ornithodoros jerseyi (Klompen and Grimaldi, 2001) (Carios). Fossil.

54. Ornithodoros jul Schulze, 1940 (Alectorobius, Carios)

55. Ornithodoros kelleyi Cooley and Kohls, 1941 (Alectorobius, Carios)

56. Ornithodoros knoxjonesi Jones and Clifford, 1972 (Alectorobius, Carios). We consider this name provisionally valid, pending comparison with $O$. dyeri (Guglielmone et al. 2009).

57. Ornithodoros kohlsi Guglielmone and Keirans, 2002 (Alectorobius, Carios). Originally named $O$. boliviensis Kohls and Clifford, 1964, which is preoccupied (Guglielmone et al. 2009).

58. Ornithodoros lahorensis Neumann, 1908 (Alveonasus, Argas). This is the type species of the genus Alveonasus.

59. Ornithodoros macmillani Hoogstraal and Kohls, 1966 (Alectorobius)

60. Ornithodoros madagascariensis Hoogstraal, 1962 (Alectorobius, Carios)

61. Ornithodoros marinkellei Kohls, Clifford and Jones, 1969 (Alectorobius, Carios)

62. Ornithodoros maritimus Vermeil and Marguet, 1967 (Alectorobius, Carios)

63. Ornithodoros marmosae Jones and Clifford, 1972 (Alectorobius, Carios)

64. Ornithodoros marocanus Velu, 1919. We consider this name provisionally valid, pending type comparison with $O$. erraticus (Guglielmone et al. 2009).

65. Ornithodoros mimon Kohls, Clifford and Jones, 1969 (Alectorobius, Carios)

66. Ornithodoros mormoops Kohls, Clifford and Jones, 1969 (Alectorobius, Carios)

67. Ornithodoros moubata (Murray, 1877)

68. Ornithodoros muesebecki Hoogstraal, 1969 (Alectorobius, Carios)

69. Ornithodoros multisetosus (Klompen, Keirans and Durden, 1995) (Alectorobius, Carios)

70. Ornithodoros natalinus Černý and Dusbábek, 1967 (Alectorobius, Carios)

71. Ornithodoros nattereri Warburton, 1927. We consider this name provisionally valid, pending comparison with $O$. rostratus (Guglielmone et al. 2009).

72. Ornithodoros nicollei Mooser, 1932

73. Ornithodoros normandi Larrousse, 1923 (Alectorobius)

74. Ornithodoros papuensis (Klompen, Keirans and Durden, 1995) (Alectorobius, Carios)

75. Ornithodoros papillipes (Birula, 1895) (Alectorobius). This species is considered a synonym of $O$. tholozani by many Western scientists (Hoogstraal, 1985), but East European workers strongly defend the validity of this name with arguments that are scientifically sound (Filippova, 1966). The uncertain status of these taxa has led us to treat them both as provisionally valid.

76. Ornithodoros parkeri Cooley, 1936 (Alectorobius)

77. Ornithodoros peringueyi Bedford and Hewitt, 1925 (Argas, Ogadenus)

78. Ornithodoros peropteryx Kohls, Clifford and Jones, 1969 (Alectorobius, Carios)

79. Ornithodoros peruvianus Kohls, Clifford and Jones, 1969 (Alectorobius, Carios)

80. Ornithodoros peusi (Schulze, 1943) (Argas, Ogadenus)

81. Ornithodoros piriformis Warburton, 1918 (Alectorobius, Carios)

82. Ornithodoros porcinus Walton, 1962

83. Ornithodoros procaviae Theodor and Costa, 1960 (Alectorobius)

84. Ornithodoros puertoricensis Fox, 1947 (Alectorobius, Carios)

85. Ornithodoros rennellensis Clifford and Sonenshine, 1962 (Alectorobius, Carios)

86. Ornithodoros rioplatensis Venzal, Estrada-Peña and Mangold, 2008 (Alectorobius, Carios)

87. Ornithodoros rondoniensis (Labruna, Terassini, Camargo, Brandão, Ribeiro and Estrada-Peña, 2008) (Alectorobius, Carios).

88. Ornithodoros rossi Kohls, Sonenshine and Clifford, 1965 (Alectorobius, Carios)

89. Ornithodoros rostratus Aragão, 1911 
90. Ornithodoros rudis Karsch, 1880 (Alectorobius, Carios)

91. Ornithodoros salahi Hoogstraal, 1953 (Alectorobius, Carios)

92. Ornithodoros savignyi (Audouin, 1826). This is the type species of the genus Ornithodoros; it was originally named Argas savignyi. There is discrepancy concerning the year of description, which some authors consider to be 1827; this discrepancy also includes the reference for the description.

93. Ornithodoros sawaii Kitaoka and Suzuki, 1973 (Alectorobius, Carios)

94. Ornithodoros setosus Kohls, Clifford and Jones, 1969 (Alectorobius, Carios)

95. Ornithodoros solomonis Dumbleton, 1959 (Alectorobius, Carios)

96. Ornithodoros sonrai Sautet and Witkowski, 1943 (Alectorobius)

97. Ornithodoros sparnus Kohls and Clifford, 1963 (Alectorobius, Otobius)

98. Ornithodoros spheniscus Hoogstraal, Wassef, Hays and Keirans, 1985 (Alectorobius, Carios)

99. Ornithodoros stageri Cooley and Kohls, 1941 (Alectorobius, Carios)

100. Ornithodoros tadaridae Černý and Dusbábek, 1967 (Alectorobius, Carios)

101. Ornithodoros talaje (Guérin-Méneville, 1849) (Alectorobius, Carios). This is the type species of the genus Alectorobius; it was originally named Argas talaje. See also $O$. dugesi.

102. Ornithodoros tartakovskyi Olenev, 1931 (Alectorobius)

103. Ornithodoros tholozani (Laboulbène and Mégnin, 1882) (Alectorobius). See also O. papillipes.

104. Ornithodoros tiptoni Jones and Clifford, 1972 (Alectorobius, Carios)

105. Ornithodoros turicata (Dugès, 1876) (Alectorobius)

106. Ornithodoros tuttlei Jones and Clifford, 1972 (Alectorobius, Carios)

107. Ornithodoros vansomereni Keirans, Hoogstraal and Clifford, 1977 (Argas, Ogadenus)

108. Ornithodoros verrucosus Olenev, Zasukhin and Fenyuk, 1934 (Alectorobius) is considered a synonym of $O$. asperus by Western workers (Hoogstraal, 1985), but Russian scientists present sound evidence for its validity (Filippova, 1966). We tentatively accept both taxa, pending further studies.

109. Ornithodoros viguerasi Cooley and Kohls, 1941 (Alectorobius, Carios)

110. Ornithodoros yumatensis Cooley and Kohls, 1941 (Alectorobius, Carios)

111. Ornithodoros yunkeri Keirans, Clifford and Hoogstraal, 1984 (Alectorobius, Carios)

112. Ornithodoros zumpti Heisch and Guggisberg, 1953 (Alectorobius)

1. Otobius lagophilus Cooley and Kohls, 1940

2. Otobius megnini (Dugès, 1883). This is the type species of the genus Otobius; it was originally named Argas megnini.

\section{Ixodidae}

We exclude the following names from our list of Ixodidae:

(i) Amblyomma laticaudae Warburton, 1933 is considered valid in Camicas et al. (1998), Horak et al. (2002) and Barker and Murrell (2008); Guglielmone et al. (2009) do not include it in their list of controversial names, while Kolonin (2009) considers this name a synonym of Amblyomma nitidum Hirst and Hirst, 1910. In fact, Keirans, in Voltzit and Keirans (2002), determined that the types of these taxa are conspecific. Therefore, we agree with Kolonin (2009) that A. laticaudae is an invalid name.

(ii) Bothriocroton decorosum (Koch, 1867) is included as a member of Aponomma by Kolonin (2009), but this name is a synonym of $B$. undatum, as explained in Santos Dias (1993).

(iii) Haemaphysalis vietnamensis Hoogstraal and Wilson, 1966 is included as a valid name in Kolonin (2009), but it is a synonym of $H$. colasbelcouri (Guglielmone et al. 2009).

(iv) Haemaphysalis xinjiangensis Teng, 1980 is not included as a valid species in Kolonin (2009). Teng and Jiang (1981) consider this name a synonym of $H$. danieli, and we accept their decision, since the senior author also described $H$. xinjiangensis.

(v) Hyalomma erythraeum Tonelli-Rondelli, 1932 is included as a valid name in Kolonin (2009), but it was convincingly shown to be a synonym of $H$. impeltatum by Apanaskevich and Horak (2009). 
(vi) Rhipicephalus hoogstraali Kolonin, 2009 was described on the Internet, contrary to the rules of the International Code of Zoological Nomenclature (International Commission on Zoological Nomenclature, 2009, Articles 8.6 and 9.8), and is therefore a nomen nudum.

1. Amblyomma albolimbatum Neumann, 1907

2. Amblyomma albopictum Neumann, 1899

3. Amblyomma americanum (Linnaeus, 1758)

4. Amblyomma antillorum Kohls, 1969

5. Amblyomma arcanum Karsch, 1879 (Aponomma)

6. Amblyomma argentinae Neumann, 1905. Guglielmone et al. (2003) stated that the year of description for A. argentinae is 1904, but this is in error because Neumann recognized 1905 as the correct year. Previously, this species was incorrectly named A. testudinis (Guglielmone et al. 2009).

7. Amblyomma astrion Dönitz, 1909

8. Amblyomma aureolatum (Pallas, 1772)

9. Amblyomma auricularium (Conil, 1878)

10. Amblyomma australiense Neumann, 1905. See A. echidnae.

11. Amblyomma babirussae Schulze, 1933

12. Amblyomma beaurepairei Vogelsang and Santos Dias, 1953. This species is close to A. inornatum and A. auricularium but is provisionally considered valid in Guglielmone et al. (2009). However, Kolonin (2009) considers it a synonym of $A$. auricularium.

13. Amblyomma boeroi Nava, Mangold, Mastropaolo, Venzal, Oscherov and Guglielmone, 2009

14. Amblyomma boulengeri Hirst and Hirst, 1910

15. Amblyomma brasiliense Aragão, 1908

16. Amblyomma breviscutatum Neumann, 1899. Until recently, this species was known as A. cyprium Neumann, 1899 (Guglielmone et al. 2009), a name still considered valid in Kolonin (2009), who does not justify his position. However, Keirans, in Voltzit and Keirans (2002), determined, as had Santos Dias (1956) before him, that the types of A. cyprium and A. breviscutatum are conspecific and that the latter name has page priority.

17. Amblyomma cajennense (Fabricius, 1787). This is the type species of the genus Amblyomma; it was originally named Acarus cajennensis. Beati, L. and Nava, S. (pers. comm.) believe that A. cajennense comprises a complex of sibling species.

18. Amblyomma calabyi Roberts, 1963

19. Amblyomma calcaratum Neumann, 1899

20. Amblyomma chabaudi Rageau, 1964

21. Amblyomma clypeolatum Neumann, 1899

22. Amblyomma coelebs Neumann, 1899

23. Amblyomma cohaerens Dönitz, 1909

24. Amblyomma compressum (Macalister, 1872)

25. Amblyomma cordiferum Neumann, 1899

26. Amblyomma crassipes (Neumann, 1901) (Aponomma). This species is similar to A. fuscolineatum but is provisionally considered valid because little material is available for examination and the types have not been compared (Guglielmone et al. 2009). Kolonin (2009), using the name Aponomma, considers A. crassipes invalid but does not include a comparison of types.

27. Amblyomma crassum Robinson, 1926

28. Amblyomma crenatum Neumann, 1899

29. Amblyomma cruciferum Neumann, 1901

30. Amblyomma darwini Hirst and Hirst, 1910

31. Amblyomma dissimile Koch, 1844. Guglielmone et al. (2009) argue in favor of this name instead of $A$. bibroni (Gervais, 1842) because of the confused history of the latter taxon. 
32. Amblyomma dubitatum Neumann, 1899. Until recently, this species was known as A. cooperi Nuttall and Warburton, 1908 (Guglielmone et al. 2009).

33. Amblyomma eburneum Gerstäcker, 1873

34. Amblyomma echidnae Roberts, 1953 . This species is very similar to A. australiense, but Guglielmone et al. (2009) consider A. echidnae provisionally valid until its status can be clarified. Kolonin (2009) does not include this species in his list of the Ixodidae of the world.

35. Amblyomma elaphense (Price, 1959) (Aponomma). See A. sphenodonti.

36. Amblyomma exornatum Koch, 1844 (Aponomma)

37. Amblyomma extraoculatum Neumann, 1899. See A. romitii.

38. Amblyomma falsomarmoreum Tonelli-Rondelli, 1935

39. Amblyomma fimbriatum Koch, 1844 (Aponomma)

40. Amblyomma flavomaculatum (Lucas, 1846) (Aponomma). See A. inopinatum.

41. Amblyomma fulvum Neumann, 1899

42. Amblyomma fuscolineatum (Lucas, 1847) (Aponomma). See A. crassipes and A. varanense.

43. Amblyomma fuscum Neumann, 1907. A valid taxon ignored in some lists of ticks (Guglielmone et al. 2009).

44. Amblyomma geayi Neumann, 1899. Guglielmone et al. (2009) discuss the lack of agreement concerning this name, because some authors regard A. geayi as a synonym of A. perpunctatum (Packard, 1869). However, the description of the latter taxon is inadequate, and we therefore consider the name A. geayi valid, pending type comparison.

45. Amblyomma gemma Dönitz, 1909

46. Amblyomma geochelone Durden, Keirans and Smith, 2002

47. Amblyomma geoemydae (Cantor, 1847)

48. Amblyomma gervaisi (Lucas, 1847) (Aponomma). This is the type species of the genus Aponomma; it was originally named Ixodes gervaisii.

49. Amblyomma glauerti Keirans, King and Sharrad, 1994

50. Amblyomma goeldii Neumann, 1899

51. Amblyomma hainanense Teng, 1981. Kolonin (2009) considers A. hainanense a synonym of A. helvolum, but no comparison of types has been attempted. Therefore, we treat $A$. hainanense as tentatively valid.

52. Amblyomma hebraeum Koch, 1844

53. Amblyomma helvolum Koch, 1844

54. Amblyomma hirtum Neumann, 1906

55. Amblyomma humerale Koch, 1844

56. Amblyomma imitator Kohls, 1958

57. Amblyomma incisum Neumann, 1906. See A. latepunctatum.

58. Amblyomma inopinatum (Santos Dias, 1989) (Aponomma). This species is not included in Kolonin (2009), who appears to consider it a synonym of A. flavomaculatum and places it in the genus Aponomma.

59. Amblyomma inornatum (Banks, 1909)

60. Amblyomma integrum Karsch, 1879

61. Amblyomma javanense (Supino, 1897)

62. Amblyomma komodoense (Oudemans, 1928) (Aponomma)

63. Amblyomma kraneveldi (Anastos, 1956) (Aponomma)

64. Amblyomma latepunctatum Tonelli-Rondelli, 1939. This species was previously confused with A. incisum and with A. scalpturatum (Guglielmone et al. 2009).

65. Amblyomma latum Koch, 1844 (Aponomma)

66. Amblyomma lepidum Dönitz, 1909

67. Amblyomma limbatum Neumann, 1899

68. Amblyomma loculosum Neumann, 1907

69. Amblyomma longirostre (Koch, 1844) 
70. Amblyomma macfarlandi Keirans, Hoogstraal and Clifford, 1973

71. Amblyomma macropi Roberts, 1953

72. Amblyomma maculatum Koch, 1844

73. Amblyomma marmoreum Koch, 1844

74. Amblyomma moreliae (Koch, 1867)

75. Amblyomma moyi Roberts, 1953

76. Amblyomma multipunctum Neumann, 1899

77. Amblyomma naponense (Packard, 1869)

78. Amblyomma neumanni Ribaga, 1902. Nava et al. (2009a) state that the description by Voltzit (2007) of A. neumanni actually applies to A. parvitarsum.

79. Amblyomma nitidum Hirst and Hirst, 1910. See paragraph "i” above our list of Ixodidae.

80. Amblyomma nodosum Neumann, 1899

81. Amblyomma nuttalli Dönitz, 1909

82. Amblyomma oblongoguttatum Koch, 1844

83. Amblyomma orlovi (Kolonin, 1992) (Aponomma). This species is considered tentatively valid in Guglielmone et al. (2009), who nonetheless strongly suggest that it is a synonym of A. transversale. Guglielmone et al. (2009) err in listing the date of description as 1995.

84. Amblyomma ovale Koch, 1844

85. Amblyomma pacae Aragão, 1911

86. Amblyomma papuanum Hirst, 1914

87. Amblyomma parkeri Fonseca and Aragão, 1952. Kolonin (2009) expresses doubt about the status of this species, but Labruna et al. (2009a) present sound evidence for its validity.

88. Amblyomma parvitarsum Neumann, 1901. See A. neumanni.

89. Amblyomma parvum Aragão, 1908

90. Amblyomma pattoni (Neumann, 1910) (Aponomma)

91. Amblyomma paulopunctatum Neumann, 1899

92. Amblyomma pecarium Dunn, 1933

93. Amblyomma personatum Neumann, 1901

94. Amblyomma pictum Neumann, 1906

95. Amblyomma pilosum Neumann, 1899

96. Amblyomma pomposum Dönitz, 1909

97. Amblyomma postoculatum Neumann, 1899

98. Amblyomma pseudoconcolor Aragão, 1908

99. Amblyomma pseudoparvum Guglielmone, Mangold and Keirans, 1990

100. Amblyomma quadricavum (Schulze, 1941)

101. Amblyomma rhinocerotis (de Geer, 1778)

102. Amblyomma robinsoni Warburton, 1927

103. Amblyomma romitii Tonelli-Rondelli, 1939. This species was previously considered a synonym of $A$. extraoculatum (Guglielmone et al. 2009).

104. Amblyomma rotundatum Koch, 1844

105. Amblyomma sabanerae Stoll, 1894

106. Amblyomma scalpturatum Neumann, 1906. See A. latepunctatum.

107. Amblyomma scutatum Neumann, 1899

108. Amblyomma soembawense (Anastos, 1956) (Aponomma)

109. Amblyomma sparsum Neumann, 1899

110. Amblyomma sphenodonti (Dumbleton, 1943) (Aponomma). Miller et al. (2007) believe that this species, and possibly A. elaphense, should be classified in a genus other than Amblyomma.

111. Amblyomma splendidum Giebel, 1877

112. Amblyomma squamosum Kohls, 1953

113. Amblyomma supinoi Neumann, 1904 
114. Amblyomma sylvaticum (de Geer, 1778)

115. Amblyomma tapirellum Dunn, 1933

116. Amblyomma testudinarium Koch, 1844

117. Amblyomma tholloni Neumann, 1899

118. Amblyomma tigrinum Koch, 1844

119. Amblyomma torrei Pérez Vigueras, 1934

120. Amblyomma transversale (Lucas, 1845) (Aponomma). Most authors consider 1844 the year of description of A. transversale, but the name Ixodes transversalis in Lucas (1844) lacks a description (i.e., it is a nomen nudum), and this situation was amended in Lucas (1845). See A. orlovi.

121. Amblyomma triguttatum Koch, 1844

122. Amblyomma trimaculatum (Lucas, 1878) (Aponomma)

123. Amblyomma triste Koch, 1844

124. Amblyomma tuberculatum Marx, 1894

125. Amblyomma usingeri Keirans, Hoogstraal and Clifford, 1973

126. Amblyomma varanense (Supino, 1897) (Aponomma). Kolonin (2009) considers A. varanense a synonym of A. fuscolineatum (both are treated as species of Aponomma) but without presenting evidence. We believe $A$. varanense to be valid.

127. Amblyomma variegatum (Fabricius, 1794)

128. Amblyomma varium Koch, 1844

129. Amblyomma vikirri Keirans, Bull and Duffield, 1996

130. Amblyomma williamsi Banks, 1924

1. Anomalohimalaya cricetuli Teng and Huang, 1981. Deng et al. (1999) consider this species a synonym of A. lotozkyi but without explanation. We therefore maintain the validity of A. cricetuli.

2. Anomalohimalaya lamai Hoogstraal, Kaiser and Mitchell, 1970. This is the type species of the genus Anomalohimalaya.

3. Anomalohimalaya lotozkyi Filippova and Panova, 1978. See A. cricetuli.

1. Bothriocroton auruginans (Schulze, 1936) (Aponomma)

2. Bothriocroton concolor (Neumann, 1899) (Aponomma). See B. oudemansi.

3. Bothriocroton glebopalma (Keirans, King and Sharrad, 1994) (Aponomma). This is the type species of the genus Bothriocroton, by original designation (Klompen et al. 2002); it was originally named Aponomma glebopalma.

4. Bothriocroton hydrosauri (Denny, 1843) (Aponomma). See B. tachyglossi.

5. Bothriocroton oudemansi (Neumann, 1910) (Aponomma). This species was considered a synonym of $B$. concolor, but there is now sound scientific evidence for its validity as a species (Guglielmone et al. 2009).

6. Bothriocroton tachyglossi (Roberts, 1953) (Aponomma). This species was considered a synonym of $B$. hydrosauri, but there is now convincing evidence for its validity (Guglielmone et al. 2009).

7. Bothriocroton undatum (Fabricius, 1775) (Aponomma). This name is considered invalid by Kolonin (2009). See B. decorosum, paragraph "ii" above our list of Ixodidae.

1. Compluriscutula vetulum Poinar and Buckley, 2008. This is the type species of the fossil genus Compluriscutula. It is not included in the list of Kolonin (2009).

1. Cornupalpatum burmanicum Poinar and Brown, 2003. This is the type species of the fossil genus Cornupalpatum. It is not included in the list of Kolonin (2009).

2. Cosmiomma hippopotamensis (Denny, 1843). This is the type species of the monotypic genus Cosmiomma. It was originally named Ixodes hippopotamensis. 
1. Dermacentor abaensis Teng, 1963. This species is similar to D. everestianus but is provisionally considered valid in Guglielmone et al. (2009) because there has been no definitive study to support this synonymy. One of us (DAA) is currently comparing the types of D. abaensis, D. everestianus and D. birulai Olenev, 1927. Therefore, additional information on the specific status of these taxa should be forthcoming.

2. Dermacentor albipictus (Packard, 1869)

3. Dermacentor andersoni Stiles, 1908

4. Dermacentor asper Arthur, 1960. Kolonin (2009) considers D. asper a probable synonym of $D$. sinicus but presents no evidence for this statement.

5. Dermacentor atrosignatus Neumann, 1906

6. Dermacentor auratus Supino, 1897

7. Dermacentor circumguttatus Neumann, 1897

8. Dermacentor compactus Neumann, 1901

9. Dermacentor confragus (Schulze, 1933). Originally spelled confractus, the name was later corrected to confragus. The type specimens are currently being examined by one of us (TNP). We consider this name valid until studies of the type material permit a conclusive statement. Kolonin (2009) excludes this name from his list of ixodid ticks of the world.

10. Dermacentor dispar Cooley, 1937

11. Dermacentor dissimilis, Cooley 1947

12. Dermacentor everestianus Hirst, 1926. See D. abaensis.

13. Dermacentor halli McIntosh, 1931

14. Dermacentor hunteri Bishopp, 1912

15. Dermacentor imitans Warburton, 1933

16. Dermacentor latus Cooley, 1937

17. Dermacentor marginatus (Sulzer, 1776). See D. niveus and D. ushakovae.

18. Dermacentor montanus Filippova and Panova, 1974

19. Dermacentor nitens Neumann, 1897 (Anocentor). This is the type species of the genus Anocentor.

20. Dermacentor niveus Neumann, 1897. Kolonin (2009) lists this species as a synonym of $D$. daghestanicus Olenev, 1928, but, in fact, the latter name is a junior synonym of D. niveus (Guglielmone et al. 2009). Estrada-Peña and Estrada-Peña (1991) examined part of the syntype series of D. niveus (Cherestanek, Iran, ex Ovis aries, 1882, loaned by Prof. P.-C. Morel), concluding that this species is conspecific with $D$. marginatus, a view shared by Moshaverinia et al. (2009). A wider comparative study of $D$. marginatus, $D$. niveus and $D$. ushakovae appears to be needed to further demonstrate the validity of these taxa. We consider $D$. niveus provisionally valid while awaiting the results of this comparison. See also D. ushakovae.

21. Dermacentor nuttalli Olenev, 1928

22. Dermacentor occidentalis Marx, 1892

23. Dermacentor parumapertus Neumann, 1901

24. Dermacentor pavlovskyi Olenev, 1927

25. Dermacentor pomerantzevi Serdjukova, 1951

26. Dermacentor raskemensis Pomerantzev, 1946

27. Dermacentor reticulatus (Fabricius, 1794). This is the type species of the genus Dermacentor. It was originally named Acarus reticulatus.

28. Dermacentor rhinocerinus (Denny, 1843)

29. Dermacentor silvarum Olenev, 1931

30. Dermacentor sinicus Schulze, 1932. See D. asper.

31. Dermacentor steini (Schulze, 1933)

32. Dermacentor taiwanensis Sugimoto, 1935

33. Dermacentor ushakovae Filippova and Panova, 1987. Guglielmone et al. (2009) state that Camicas et al. (1998) consider $D$. ushakovae a junior synonym of $D$. niveus, while one of us (AEP) regards this species as a junior synonym of $D$. marginatus. However, we have elected to recognize the validity of $D$. ushakovae until type comparisons clarify its status. See also $D$. niveus. 


\section{Dermacentor variabilis (Say, 1821)}

1. Haemaphysalis aborensis Warburton, 1913

2. Haemaphysalis aciculifer Warburton, 1913

3. Haemaphysalis aculeata Lavarra, 1904

4. Haemaphysalis adleri Feldman-Muhsam, 1951

5. Haemaphysalis anomala Warburton, 1913

6. Haemaphysalis anomaloceraea Teng, 1984. Guglielmone et al. (2009) state that Camicas et al. (1998) consider this species a synonym of $H$. shimoga, but we continue to treat it as valid because there are no published grounds for synonymization. Kolonin (2009) considers both taxa (H. anomaloceraea and $H$. shimoga) to be synonyms of $H$. taiwana but presents no justification for this position.

7. Haemaphysalis anoplos Hoogstraal, Uilenberg and Klein, 1967

8. Haemaphysalis aponommoides Warburton, 1913

9. Haemaphysalis asiatica (Supino, 1897)

10. Haemaphysalis atheruri Hoogstraal, Trapido and Kohls, 1965

11. Haemaphysalis bancrofti Nuttall and Warburton, 1915

12. Haemaphysalis bandicota Hoogstraal and Kohls, 1965

13. Haemaphysalis bartelsi Schulze, 1938

14. Haemaphysalis bequaerti Hoogstraal, 1956

15. Haemaphysalis birmaniae Supino, 1897

16. Haemaphysalis bispinosa Neumann, 1897

17. Haemaphysalis borneata Hoogstraal, 1971

18. Haemaphysalis bremneri Roberts, 1963

19. Haemaphysalis calcarata Neumann, 1902

20. Haemaphysalis calva Nuttall and Warburton, 1915

21. Haemaphysalis campanulata Warburton, 1908

22. Haemaphysalis canestrinii (Supino, 1897)

23. Haemaphysalis capricornis Hoogstraal, 1966

24. Haemaphysalis caucasica Olenev, 1928

25. Haemaphysalis celebensis Hoogstraal, Trapido and Kohls, 1965

26. Haemaphysalis chordeilis (Packard, 1869)

27. Haemaphysalis cinnabarina Koch, 1844. This species is not included in Kolonin's (2009) list of ixodid ticks.

28. Haemaphysalis colasbelcouri (Santos Dias, 1958). Originally named Aponomma colasbelcouri Santos Dias, 1958 , this species is the senior synonym of $H$. vietnamensis (see $H$. vietnamensis, paragraph "iii" above our list of Ixodidae) (Guglielmone et al. 2009).

29. Haemaphysalis colesbergensis Apanaskevich and Horak, 2008. This species is not included in Kolonin's (2009) list of ixodid ticks.

30. Haemaphysalis concinna Koch, 1844. This is the type species of the genus Haemaphysalis. See also H. filippovae.

31. Haemaphysalis cooleyi Bedford, 1929

32. Haemaphysalis cornigera Neumann, 1897

33. Haemaphysalis cornupunctata Hoogstraal and Varma, 1962

34. Haemaphysalis cuspidata Warburton, 1910

35. Haemaphysalis dangi Phan Trong, 1977

36. Haemaphysalis danieli Černý and Hoogstraal, 1977. See paragraph "iv" above our list of Ixodidae. Kolonin (2009) considers specimens of this taxon from China a synonym of $H$. pospelovashtromae but provides no supporting evidence.

37. Haemaphysalis darjeeling Hoogstraal and Dhanda, 1970

38. Haemaphysalis davisi Hoogstraal, Dhanda and Bhat, 1970 
39. Haemaphysalis demidovae Emel'yanova, 1978

40. Haemaphysalis doenitzi Warburton and Nuttall, 1909. See H. pavlovskyi and H. phasiana.

41. Haemaphysalis elliptica (Koch, 1844)

42. Haemaphysalis elongata Neumann, 1897

43. Haemaphysalis erinacei Pavesi, 1884

44. Haemaphysalis eupleres Hoogstraal, Kohls and Trapido, 1965

45. Haemaphysalis filippovae Bolotin, 1979. Although Kolonin (2009) considers H. filippovae a synonym of $H$. concinna, Guglielmone et al. (2009) provide strong arguments for supporting the validity of this taxon.

46. Haemaphysalis flava Neumann, 1897

47. Haemaphysalis formosensis Neumann, 1913

48. Haemaphysalis fossae Hoogstraal, 1953

49. Haemaphysalis fujisana Kitaoka, 1970

50. Haemaphysalis garhwalensis Dhanda and Bhat, 1968

51. Haemaphysalis goral Hoogstraal, 1970

52. Haemaphysalis grochovskajae Kolonin, 1992. Kolonin (2009) spells this name as H. grochovskaja (n. syn.).

53. Haemaphysalis heinrichi Schulze, 1939

54. Haemaphysalis hirsuta Hoogstraal, Trapido and Kohls, 1966

55. Haemaphysalis hispanica Gil Collado, 1938

56. Haemaphysalis hoodi Warburton and Nuttall, 1909

57. Haemaphysalis hoogstraali Kohls, 1950

58. Haemaphysalis houyi Nuttall and Warburton, 1915

59. Haemaphysalis howletti Warburton, 1913

60. Haemaphysalis humerosa Warburton and Nuttall, 1909

61. Haemaphysalis hylobatis Schulze, 1933

62. Haemaphysalis hyracophila Hoogstraal, Walker and Neitz, 1971

63. Haemaphysalis hystricis Supino, 1897

64. Haemaphysalis ias Nakamura and Yajima, 1937

65. Haemaphysalis indica Warburton, 1910

66. Haemaphysalis indoflava Dhanda and Bhat, 1968

67. Haemaphysalis inermis Birula, 1895

68. Haemaphysalis intermedia Warburton and Nuttall, 1909

69. Haemaphysalis japonica Warburton, 1908

70. Haemaphysalis juxtakochi Cooley, 1946

71. Haemaphysalis kadarsani Hoogstraal and Wassef, 1977

72. Haemaphysalis kashmirensis Hoogstraal and Varma, 1962

73. Haemaphysalis kinneari Warburton, 1913

74. Haemaphysalis kitaokai Hoogstraal, 1969

75. Haemaphysalis knobigera Prakasan and Ramani, 2007. The original description of this species is very poor and we strongly doubt its validity (Guglielmone et al. 2009), but we include it here pending further studies. Kolonin (2009) does not include H. knobigera in his list of the Ixodidae of the world.

76. Haemaphysalis koningsbergeri Warburton and Nuttall, 1909

77. Haemaphysalis kopetdaghica Kerbabaev, 1962. Kolonin (2009) spells this name as H. kopetdagica (n. syn.).

78. Haemaphysalis kutchensis Hoogstraal and Trapido, 1963

79. Haemaphysalis kyasanurensis Trapido, Hoogstraal and Rajagopalan, 1964

80. Haemaphysalis lagostrophi Roberts, 1963

81. Haemaphysalis lagrangei Larrousse, 1925

82. Haemaphysalis laocayensis Phan Trong, 1977

83. Haemaphysalis leachi (Audouin, 1826) 
84. Haemaphysalis lemuris Hoogstraal, 1953

85. Haemaphysalis leporispalustris (Packard, 1869)

86. Haemaphysalis lobachovi Kolonin, 1995

87. Haemaphysalis longicornis Neumann, 1901

88. Haemaphysalis luzonensis Hoogstraal and Parrish, 1968

89. Haemaphysalis madagascariensis Colas-Belcour and Millot, 1948

90. Haemaphysalis mageshimaensis Saito and Hoogstraal, 1973

91. Haemaphysalis megalaimae Rajagopalan, 1963

92. Haemaphysalis megaspinosa Saito, 1969

93. Haemaphysalis menglaensis Pang, Chen and Xiang, 1982

94. Haemaphysalis minuta Kohls, 1950

95. Haemaphysalis mjoebergi Warburton, 1926

96. Haemaphysalis montgomeryi Nuttall, 1912

97. Haemaphysalis moreli Camicas, Hoogstraal and El Kammah, 1972

98. Haemaphysalis moschisuga Teng, 1980

99. Haemaphysalis muhsamae Santos Dias, 1954. This species is ignored in the Kolonin (2009) list.

100. Haemaphysalis nadchatrami Hoogstraal, Trapido and Kohls, 1965

101. Haemaphysalis nepalensis Hoogstraal, 1962

102. Haemaphysalis nesomys Hoogstraal, Uilenberg and Klein, 1966

103. Haemaphysalis norvali Hoogstraal and Wassef, 1983

104. Haemaphysalis novaeguineae Hirst, 1914

105. Haemaphysalis obesa Larrousse, 1925

106. Haemaphysalis obtusa Dönitz, 1910

107. Haemaphysalis oliveri Apanaskevich and Horak, 2008. This species is not included in the Kolonin (2009) list of ixodid ticks.

108. Haemaphysalis orientalis Nuttall and Warburton, 1915

109. Haemaphysalis ornithophila Hoogstraal and Kohls, 1959

110. Haemaphysalis palawanensis Kohls, 1950

111. Haemaphysalis papuana Thorell, 1883

112. Haemaphysalis paraleachi Camicas, Hoogstraal and El Kammah, 1983

113. Haemaphysalis paraturturis Hoogstraal, Trapido and Rebello, 1963

114. Haemaphysalis parmata Neumann, 1905

115. Haemaphysalis parva (Neumann, 1897)

116. Haemaphysalis pavlovskyi Pospelova-Shtrom, 1935. Guglielmone et al. (2009) provide strong arguments for the validity of $H$. pavlovskyi, but Kolonin (2009) regards this species as a synonym of $H$. doenitzi, a position that we consider unjustified.

117. Haemaphysalis pedetes Hoogstraal, 1972

118. Haemaphysalis pentalagi Pospelova-Shtrom, 1935

119. Haemaphysalis petrogalis Roberts, 1970

120. Haemaphysalis phasiana Saito, Hoogstraal and Wassef, 1974. Kolonin (2009) considers H. phasiana a synonym of $H$. doenitzi, but his evidence is not conclusive.

121. Haemaphysalis pospelovashtromae Hoogstraal, 1966. See H. danieli.

122. Haemaphysalis primitiva Teng, 1982

123. Haemaphysalis psalistos Hoogstraal, Kohls and Parrish, 1967

124. Haemaphysalis punctaleachi Camicas, Hoogstraal and El Kammah, 1983

125. Haemaphysalis punctata Canestrini and Fanzago, 1878

126. Haemaphysalis quadriaculeata Kolonin, 1992

127. Haemaphysalis quinghaiensis Teng, 1980. Guglielmone et al. (2009) follow Camicas et al. (1998) in stressing that the correct Latin epithet for this species is quinghaiensis, not qinghaiensis, even though the latter spelling appears in the original description. 
128. Haemaphysalis ramachandrai Dhanda, Hoogstraal and Bhat, 1970

129. Haemaphysalis ratti Kohls, 1948

130. Haemaphysalis renschi Schulze, 1933

131. Haemaphysalis roubaudi Toumanoff, 1940

132. Haemaphysalis rugosa Santos Dias, 1956

133. Haemaphysalis rusae Kohls, 1950

134. Haemaphysalis sambar Hoogstraal, 1971

135. Haemaphysalis sciuri Kohls, 1950

136. Haemaphysalis semermis Neumann, 1901

137. Haemaphysalis shimoga Trapido and Hoogstraal, 1964. See H. anomaloceraea.

138. Haemaphysalis silacea Robinson, 1912

139. Haemaphysalis silvafelis Hoogstraal and Trapido, 1963

140. Haemaphysalis simplex Neumann, 1897

141. Haemaphysalis simplicima Hoogstraal and Wassef, 1979

142. Haemaphysalis sinensis Zhang, 1981

143. Haemaphysalis spinigera Neumann, 1897

144. Haemaphysalis spinulosa Neumann, 1906

145. Haemaphysalis subelongata Hoogstraal, 1953

146. Haemaphysalis subterra Hoogstraal, El Kammah and Camicas, 1992

147. Haemaphysalis sulcata Canestrini and Fanzago, 1878

148. Haemaphysalis sumatraensis Hoogstraal, El Kammah, Kadarsan and Anastos, 1971

149. Haemaphysalis sundrai Sharif, 1928

150. Haemaphysalis suntzovi Kolonin, 1993

151. Haemaphysalis susphilippensis Hoogstraal, Kohls and Parrish, 1968

152. Haemaphysalis taiwana Sugimoto, 1936. See H. anomaloceraea.

153. Haemaphysalis tauffliebi Morel, 1965

154. Haemaphysalis theilerae Hoogstraal, 1953

155. Haemaphysalis tibetensis Hoogstraal, 1965

156. Haemaphysalis tiptoni Hoogstraal, 1953

157. Haemaphysalis toxopei Warburton, 1927. This species is ignored in Kolonin's (2009) list of the Ixodidae of the world.

158. Haemaphysalis traguli Oudemans, 1928

159. Haemaphysalis traubi Kohls, 1955

160. Haemaphysalis turturis Nuttall and Warburton, 1915.

161. Haemaphysalis verticalis Itagaki, Noda and Yamaguchi, 1944

162. Haemaphysalis vidua Warburton and Nuttall, 1909

163. Haemaphysalis warburtoni Nuttall, 1912

164. Haemaphysalis wellingtoni Nuttall and Warburton, 1908

165. Haemaphysalis yeni Toumanoff, 1944

166. Haemaphysalis zumpti Hoogstraal and El Kammah, 1974

1. Hyalomma aegyptium (Linnaeus, 1758). This is the type species of the genus Hyalomma, as discussed in Filippova (1984). It was originally named Acarus aegyptius. See also H. dromedarii.

2. Hyalomma albiparmatum Schulze, 1919. Apanaskevich \& Horak (2008) consider H. albiparmatum a valid species but did not discount the possibility that it may be conspecific with $H$. truncatum. See also $H$. nitidum.

3. Hyalomma anatolicum Koch, 1844 . See H. excavatum.

4. Hyalomma arabica Pegram, Hoogstraal and Wassef, 1982

5. Hyalomma asiaticum Schulze and Schlottke, 1930

6. Hyalomma brevipunctata Sharif, 1928 
7. Hyalomma dromedarii Koch, 1844. This is the type species of the genus Hyalomma in Camicas et al. (1998), but we agree with Filippova (1984), who considers H. aegyptium to be the type.

8. Hyalomma excavatum Koch, 1844 . This species was previously classified as a subspecies of $H$. anatolicum (Guglielmone et al. 2009).

9. Hyalomma franchinii Tonelli-Rondelli, 1932.

10. Hyalomma glabrum Delpy, 1949. This name was until recently considered a synonym of $H$. turanicum (Guglielmone et al. 2009).

11. Hyalomma hussaini Sharif, 1928

12. Hyalomma hystricis Dhanda and Raja, 1974

13. Hyalomma impeltatum Schulze and Schlottke, 1930. See H. erythraeum, paragraph "v" above our list of Ixodidae.

14. Hyalomma impressum Koch, 1844

15. Hyalomma isaaci Sharif, 1928. This species was previously classified as a subspecies of $H$. marginatum (Guglielmone et al. 2009).

16. Hyalomma kumari Sharif, 1928

17. Hyalomma lusitanicum Koch, 1844

18. Hyalomma marginatum Koch, 1844. See H. isaaci, H. rufipes and H. turanicum.

19. Hyalomma nitidum Schulze, 1919. Apanaskevich \& Horak (2008) consider H. nitidum a valid species but left open the possibility that it may be conspecific with $H$. truncatum. See also H. albiparmatum.

20. Hyalomma punt Hoogstraal, Kaiser and Pedersen, 1969

21. Hyalomma rhipicephaloides Neumann, 1901

22. Hyalomma rufipes Koch, 1844 . This species was previously classified as a subspecies of $H$. marginatum (Guglielmone et al. 2009).

23. Hyalomma schulzei Olenev, 1931

24. Hyalomma scupense Schulze, 1919. Until recently, this species was known as H. detritum Schulze, 1919 by many Western workers. Because this is an economically important tick, Guglielmone et al. (2009) proposed referring to it as $H$. scupense $(=H$. detritum) in order to avoid confusion.

25. Hyalomma somalicum Tonelli-Rondelli, 1935. This taxon was recently resurrected by Apanaskevich and Horak (2009).

26. Hyalomma truncatum Koch, 1844. See H. albiparmatum and H. nitidum.

27. Hyalomma turanicum Pomerantzev, 1946. This species was previously classified as a subspecies of $H$. marginatum (Guglielmone et al. 2009). Kolonin (2009) excludes H. turanicum from his list of ixodid ticks of the world.

1. Ixodes abrocomae Lahille, 1916. Some authors have listed the year 1916 for Lahille's original description of Ixodes abrocomae, while others have used the year 1917. An inquiry to the U.S Library of Congress failed to resolve the problem. A request to the Sociedad Chilena de Biología (publisher of Revista Chilena de Historia Natural, where the description of I. abrocomae appeared) was not answered. We consider 1916 as the year of description of I. abrocomae. See also I. sigelos.

2. Ixodes acuminatus Neumann, 1901. See I. redikorzevi.

3. Ixodes acutitarsus (Karsch, 1880)

4. Ixodes affinis Neumann, 1899

5. Ixodes albignaci Uilenberg and Hoogstraal, 1969

6. Ixodes alluaudi Neumann, 1913

7. Ixodes amarali Fonseca, 1935

8. Ixodes amersoni Kohls, 1966

9. Ixodes anatis Chilton, 1904. Some authors consider the name of this species to be I. apteridis Maskell, 1897, a nomen nudum (Guglielmone et al. 2009).

10. Ixodes andinus Kohls, 1956

11. Ixodes angustus Neumann, 1899 
12. Ixodes antechini Roberts, 1960

13. Ixodes apronophorus Schulze, 1924

14. Ixodes arabukiensis Arthur, 1959. This species is very similar to I. djaronensis, but Guglielmone et al. (2009) consider it valid pending a comparison of types. Kolonin (2009) excludes I. arabukiensis from his list of Ixodidae.

15. Ixodes aragaoi Fonseca, 1935

16. Ixodes arboricola Schulze and Schlottke, 1930

17. Ixodes arebiensis Arthur, 1956

18. Ixodes asanumai Kitaoka, 1973

19. Ixodes aulacodi Arthur, 1956

20. Ixodes auriculaelongae Arthur, 1958

21. Ixodes auritulus Neumann, 1904. This name is thought to represent an Ixodes species group (González-Acuña et al. 2009).

22. Ixodes australiensis Neumann, 1904

23. Ixodes baergi Cooley and Kohls, 1942

24. Ixodes bakeri Arthur and Clifford, 1961

25. Ixodes banksi Bishopp, 1911

26. Ixodes bedfordi Arthur, 1959

27. Ixodes bequaerti Cooley and Kohls, 1945

28. Ixodes berlesei Birula, 1895

29. Ixodes bivari Santos Dias, 1990. Kolonin (2009) does not include I. bivari in his list; apparently he regards this name as a synonym of $I$. ventalloi. One of us (AEP) examined the types of I. bivari and found that they differ from I. ventalloi, especially in the morphology of the basis capituli. Therefore, we treat I. bivari as valid.

30. Ixodes boliviensis Neumann, 1904. This species is very similar to I. diversifossus, but Guglielmone et al. (2009) consider it valid pending a comparison of types.

31. Ixodes brewsterae Keirans, Clifford and Walker, 1982

32. Ixodes browningi Arthur, 1956

33. Ixodes brumpti Morel, 1965

34. Ixodes brunneus Koch, 1844

35. Ixodes calcarhebes Arthur and Zulu, 1980

36. Ixodes caledonicus Nuttall, 1910

37. Ixodes canisuga Johnston, 1849. Teng and Jiang (1991) and Kolonin (2009) consider I. canisuga a synonym of $I$. crenulatus but provide no supporting evidence; we therefore have retained I. canisuga as valid.

38. Ixodes capromydis Èern 1966

39. Ixodes catherinei Keirans, Clifford and Walker, 1982

40. Ixodes cavipalpus Nuttall and Warburton, 1908

41. Ixodes ceylonensis Kohls, 1950

42. Ixodes chilensis Kohls, 1956

43. Ixodes colasbelcouri Arthur, 1957

44. Ixodes collocaliae Schulze, 1937

45. Ixodes columnae Takada and Fujita, 1992

46. Ixodes conepati Cooley and Kohls, 1943

47. Ixodes confusus Roberts, 1960

48. Ixodes cookei Packard, 1869

49. Ixodes cooleyi Aragão and Fonseca, 1951

50. Ixodes copei Wilson, 1980

51. Ixodes cordifer Neumann, 1908

52. Ixodes cornuae Arthur, 1960

53. Ixodes cornuatus Roberts, 1960 
54. Ixodes cornutus Lotozky, 1956. Camicas et al. (1998) consider I. cornutus a synonym of I. rugicollis, although Filippova (1977) redescribed I. cornutus as valid. We treat this species as tentatively valid, pending type comparison with I. rugicollis.

55. Ixodes corwini Keirans, Clifford and Walker, 1982

56. Ixodes crenulatus Koch, 1844. See I. canisuga and I. prokopjevi

57. Ixodes cuernavacensis Kohls and Clifford, 1966

58. Ixodes cumulatimpunctatus Schulze, 1943

59. Ixodes dampfi Cooley, 1943

60. Ixodes daveyi Nuttall, 1913

61. Ixodes dawesi Arthur, 1956

62. Ixodes dendrolagi Wilson, 1967

63. Ixodes dentatus Marx, 1899

64. Ixodes dicei Keirans and Ajohda, 2003

65. Ixodes diomedeae Arthur, 1958

66. Ixodes diversifossus Neumann, 1899. Kolonin (2009) does not include this species in his list of world Ixodidae. See also I. boliviensis.

67. Ixodes djaronensis Neumann, 1907. See I. arabukiensis

68. Ixodes domerguei Uilenberg and Hoogstraal, 1965

69. Ixodes downsi Kohls, 1957

70. Ixodes drakensbergensis Clifford, Theiler and Baker, 1975

71. Ixodes eadsi Kohls and Clifford, 1964

72. Ixodes eastoni Keirans and Clifford, 1983

73. Ixodes eichhorni Nuttall, 1916

74. Ixodes eldaricus Dzhaparidze, 1950

75. Ixodes elongatus Bedford, 1929

76. Ixodes eudyptidis Maskell, 1885

77. Ixodes euplecti Arthur, 1958

78. Ixodes evansi Arthur, 1956

79. Ixodes fecialis Warburton and Nuttall, 1909

80. Ixodes festai Tonelli-Rondelli, 1926

81. Ixodes filippovae Černý, 1961. Kolonin (2009) does not include this species in his list of ixodid ticks of the world. He is probably following Filippova (1977), who considers I. filippovae a synonym of $I$. crenulatus. In fact, the status of I. filippovae is questionable and we list this species as provisionally valid while awaiting further studies.

82. Ixodes fossulatus Neumann, 1899

83. Ixodes frontalis (Panzer, 1798)

84. Ixodes fuscipes Koch, 1844

85. Ixodes galapagoensis Clifford and Hoogstraal, 1980

86. Ixodes ghilarovi Filippova and Panova, 1988

87. Ixodes gibbosus Nuttall, 1916

88. Ixodes granulatus Supino, 1897

89. Ixodes gregsoni Lindquist, Wu and Redner, 1999

90. Ixodes guatemalensis Kohls, 1956

91. Ixodes hearlei Gregson, 1941

92. Ixodes heinrichi Arthur, 1962

93. Ixodes hexagonus Leach, 1815

94. Ixodes himalayensis Dhanda and Kulkarni, 1969

95. Ixodes hirsti Hassall, 1931

96. Ixodes holocyclus Neumann, 1899

97. Ixodes hoogstraali Arthur, 1955 
98. Ixodes howelli Cooley and Kohls, 1938

99. Ixodes hyatti Clifford, Hoogstraal and Kohls, 1971

100. Ixodes hydromyidis Swan, 1931

101. Ixodes jacksoni Hoogstraal, 1967

102. Ixodes jellisoni Cooley and Kohls, 1938

103. Ixodes jonesae Kohls, Sonenshine and Clifford, 1969

104. Ixodes kaiseri Arthur, 1957

105. Ixodes kashmiricus Pomerantzev, 1948. Guglielmone et al. (2009) asserted that the spelling kaschmiricus was correct. However, Pomerantzev (1950) amended the spelling kaschmiricus to kashmiricus, the valid name for this species.

106. Ixodes kazakstani Olenev and Sorokoumov, 1934

107. Ixodes kerguelenensis André and Colas-Belcour, 1942

108. Ixodes kingi Bishopp, 1911

109. Ixodes kohlsi Arthur, 1955

110. Ixodes kopsteini (Oudemans, 1926)

111. Ixodes kuntzi Hoogstraal and Kohls, 1965

112. Ixodes laguri Olenev, 1929

113. Ixodes lasallei Méndez Arocha and Ortiz, 1958

114. Ixodes latus Arthur, 1958

115. Ixodes laysanensis Wilson, 1964

116. Ixodes lemuris Arthur, 1958

117. Ixodes lewisi Arthur, 1965

118. Ixodes lividus Koch, 1844

119. Ixodes longiscutatus Boero, 1944

120. Ixodes loricatus Neumann, 1899

121. Ixodes loveridgei Arthur, 1958

122. Ixodes luciae Sénevet, 1940

123. Ixodes lunatus Neumann, 1907

124. Ixodes luxuriosus Schulze, 1932

125. Ixodes macfarlanei Keirans, Clifford and Walker, 1982

126. Ixodes malayensis Kohls, 1962

127. Ixodes marmotae Cooley and Kohls, 1938

128. Ixodes marxi Banks, 1908

129. Ixodes maslovi Emel'yanova and Kozlovskaya, 1967. Kolonin (2009) considers I. maslovi a synonym of I. persulcatus, but Guglielmone et al. (2009) provide arguments for its validity.

130. Ixodes matopi Spickett, Keirans, Norval and Clifford, 1981

131. Ixodes mexicanus Cooley and Kohls, 1942

132. Ixodes minor Neumann, 1902

133. Ixodes minutae Arthur, 1959

134. Ixodes mitchelli Kohls, Clifford and Hoogstraal, 1970

135. Ixodes monospinosus Saito, 1968

136. Ixodes montoyanus Cooley, 1944

137. Ixodes moreli Arthur, 1957

138. Ixodes moscharius Teng, 1982

139. Ixodes moschiferi Nemenz, 1968

140. Ixodes muniensis Arthur and Burrow, 1957

141. Ixodes muris Bishopp and Smith, 1937

142. Ixodes murreleti Cooley and Kohls, 1945

143. Ixodes myospalacis Teng, 1986

144. Ixodes myotomys Clifford and Hoogstraal, 1970 
145. Ixodes myrmecobii Roberts, 1962

146. Ixodes nairobiensis Nuttall, 1916

147. Ixodes nchisiensis Arthur, 1958

148. Ixodes nectomys Kohls, 1956

149. Ixodes neitzi Clifford, Walker and Keirans, 1977

150. Ixodes nesomys Uilenberg and Hoogstraal, 1969

151. Ixodes neuquenensis Ringuelet, 1947

152. Ixodes nicolasi Santos Dias, 1982. Kolonin (2009) excludes this species from his list of world Ixodidae.

153. Ixodes nipponensis Kitaoka and Saito, 1967

154. Ixodes nitens Neumann, 1904

155. Ixodes nuttalli Lahille, 1913

156. Ixodes nuttallianus Schulze, 1930

157. Ixodes occultus Pomerantzev, 1946

158. Ixodes ochotonae Gregson, 1941

159. Ixodes okapiae Arthur, 1956

160. Ixodes oldi Nuttall, 1913

161. Ixodes ornithorhynchi Lucas, 1846

162. Ixodes ovatus Neumann, 1899

163. Ixodes pacificus Cooley and Kohls, 1943

164. Ixodes paranaensis Barros-Battesti, Arzua, Pichorim and Keirans, 2003

165. Ixodes pararicinus Keirans and Clifford, 1985

166. Ixodes pavlovskyi Pomerantzev, 1946

167. Ixodes percavatus Neumann, 1906

168. Ixodes peromysci Augustson, 1940

169. Ixodes persulcatus Schulze, 1930. See also I. maslovi and I. sachalinensis.

170. Ixodes petauristae Warburton, 1933

171. Ixodes philipi Keirans and Kohls, 1970

172. Ixodes pilosus Koch, 1844. McKay (1994) considers that there are three species under the name $I$. pilosus. Two of us (DAA and IGH) and co-workers are currently studying I. pilosus and its alleged sibling species.

173. Ixodes pomerantzevi Serdjukova, 1941. Guglielmone et al. (2009) asserted that the spelling pomeranzevi was correct. However, Pomerantzev (1950) amended the spelling pomeranzevi to pomerantzevi, the valid name for this species.

174. Ixodes pomerantzi Kohls, 1956

175. Ixodes priscicollaris Schulze, 1932

176. Ixodes procaviae Arthur and Burrow, 1957

177. Ixodes prokopjevi (Emel'yanova, 1979). Kolonin (2009) appears to consider this species a likely synonym of $I$. crenulatus, but we find no reason to declare I. prokopjevi invalid.

178. Ixodes radfordi Kohls, 1948

179. Ixodes rageaui Arthur, 1958

180. Ixodes randrianasoloi Uilenberg and Hoogstraal, 1969

181. Ixodes rasus Neumann, 1899

182. Ixodes redikorzevi Olenev, 1927. Kolonin (2009) considers this species a synonym of I. acuminatus, but we regard it as provisionally valid.

183. Ixodes rhabdomysae Arthur, 1959

184. Ixodes ricinus (Linnaeus, 1758). This is the type species of the genus Ixodes; it was originally named Acarus ricinus.

185. Ixodes rothschildi Nuttall and Warburton, 1911

186. Ixodes rotundatus Arthur, 1958 
187. Ixodes rubicundus Neumann, 1904

188. Ixodes rubidus Neumann, 1901

189. Ixodes rugicollis Schulze and Schlottke, 1930. See I. cornutus.

190. Ixodes rugosus Bishopp, 1911

191. Ixodes sachalinensis Filippova, 1971. Kolonin (2009) considers $I$. sachalinensis a synonym of $I$. persulcatus, but Guglielmone et al. (2009) have found no evidence to support this position.

192. Ixodes scapularis Say, 1821

193. Ixodes schillingsi Neumann, 1901

194. Ixodes schulzei Aragão and Fonseca, 1951

195. Ixodes sculptus Neumann, 1904

196. Ixodes semenovi Olenev, 1929

197. Ixodes shahi Clifford, Hoogstraal and Kohls, 1971

198. Ixodes siamensis Kitaoka and Suzuki, 1983. Kolonin (2009) considers I. siamensis a synonym of $I$. ovatus, but Guglielmone et al. (2009) treat it as provisionally valid.

199. Ixodes sigelos Keirans, Clifford and Corwin, 1976. In Camicas et al. (1998), I. sigelos is listed as a synonym of I. abrocomae Lahille, 1916, but Guglielmone et al. (2009) found no evidence for this arrangement and declared both names valid. Recently, Guglielmone et al. (in press) redescribed the male and described the female of I. abrocomae, thereby settling this controversy.

200. Ixodes signatus Birula, 1895

201. Ixodes simplex Neumann, 1906

202. Ixodes sinaloa Kohls and Clifford, 1966

203. Ixodes sinensis Teng, 1977

204. Ixodes soricis Gregson, 1942

205. Ixodes spinae Arthur, 1958

206. Ixodes spinicoxalis Neumann, 1899

207. Ixodes spinipalpis Hadwen and Nuttall, 1916

208. Ixodes steini Schulze, 1932

209. Ixodes stilesi Neumann, 1911

210. Ixodes stromi Filippova, 1957

211. Ixodes subterraneus Filippova, 1961. This species was originally named I. subterranus in Filipppova (1961), but amended to I. subterraneus in Filippova (1977).

212. Ixodes succineus Weidner, 1964. Fossil. This species is not included in Kolonin (2009).

213. Ixodes taglei Kohls, 1969

214. Ixodes tamaulipas Kohls and Clifford, 1966

215. Ixodes tancitarius Cooley and Kohls, 1942

216. Ixodes tanuki Saito, 1964

217. Ixodes tapirus Kohls, 1956

218. Ixodes tasmani Neumann, 1899

219. Ixodes tecpanensis Kohls, 1956

220. Ixodes texanus Banks, 1909

221. Ixodes theilerae Arthur, 1953

222. Ixodes thomasae Arthur and Burrow, 1957

223. Ixodes tiptoni Kohls and Clifford, 1962

224. Ixodes tovari Cooley, 1945

225. Ixodes transvaalensis Clifford and Hoogstraal, 1966

226. Ixodes trianguliceps Birula, 1895

227. Ixodes trichosuri Roberts, 1960

228. Ixodes tropicalis Kohls, 1956

229. Ixodes turdus Nakatsuji, 1942

230. Ixodes ugandanus Neumann, 1906 
231. Ixodes unicavatus Neumann, 1908

232. Ixodes uriae White, 1852

233. Ixodes vanidicus Schulze, 1943

234. Ixodes venezuelensis Kohls, 1953

235. Ixodes ventalloi Gil Collado, 1936

236. Ixodes vespertilionis Koch, 1844

237. Ixodes vestitus Neumann, 1908

238. Ixodes victoriensis Nuttall, 1916

239. Ixodes walkerae Clifford, Kohls and Hoogstraal, 1968

240. Ixodes werneri Kohls, 1950

241. Ixodes woodi Bishopp, 1911

242. Ixodes zaglossi Kohls, 1960

243. Ixodes zairensis Keirans, Clifford and Walker, 1982

1. Margaropus reidi Hoogstraal, 1956

2. Margaropus wileyi Walker and Laurence, 1973

3. Margaropus winthemi Karsch, 1879. This is the type species of the genus Margaropus.

1. Nosomma monstrosum (Nuttall and Warburton, 1908). This is the type species of the formerly monotypic genus Nosomma; it was originally named Hyalomma monstrosum.

2. Nosomma keralensis Prakasan and Ramani, 2007. The original description of this species is very poor and we strongly doubt its validity (Guglielmone et al. 2009), but we include it here pending type comparison with N. monstrosum, which should readily clarify its status. Kolonin (2009) does not include this species in his list of the Ixodidae of the world.

1. Rhipicentor bicornis Nuttall and Warburton, 1908. This is the type species of the genus Rhipicentor.

2. Rhipicentor nuttalli Cooper and Robinson, 1908

1. Rhipicephalus annulatus (Say, 1821) (Boophilus). This is the type species of the genus Boophilus. This species was originally named Ixodes annulatus.

2. Rhipicephalus appendiculatus Neumann, 1901

3. Rhipicephalus aquatilis Walker, Keirans and Pegram, 1993

4. Rhipicephalus armatus Pocock, 1900

5. Rhipicephalus arnoldi Theiler and Zumpt, 1949

6. Rhipicephalus aurantiacus Neumann, 1907. Guglielmone et al. (2009) note that this tick is considered a synonym of $R$. ziemanni by some authors, but because there has been no comparison of types, we provisionally regard $R$. aurantiacus as valid. Kolonin (2009) does not include $R$. aurantiacus in his list of world Ixodidae.

7. Rhipicephalus bequaerti Zumpt, 1949

8. Rhipicephalus bergeoni Morel and Balis, 1976

9. Rhipicephalus boueti Morel, 1957

10. Rhipicephalus bursa Canestrini and Fanzago, 1878

11. Rhipicephalus camicasi Morel, Mouchet and Rodhain, 1976

12. Rhipicephalus capensis Koch, 1844

13. Rhipicephalus carnivoralis Walker, 1966

14. Rhipicephalus cliffordi Morel, 1965. Guglielmone et al. (2009) note that this tick has been considered a synonym of $R$. pseudolongus, but because there has been no comparison of types, we provisionally regard $R$. cliffordi as valid. Kolonin (2009) does not share this opinion.

15. Rhipicephalus complanatus Neumann, 1911

16. Rhipicephalus compositus Neumann, 1897 
17. Rhipicephalus cuspidatus Neumann, 1906

18. Rhipicephalus decoloratus Koch, 1844 (Boophilus)

19. Rhipicephalus deltoideus Neumann, 1910

20. Rhipicephalus distinctus Bedford, 1932

21. Rhipicephalus duttoni Neumann, 1907

22. Rhipicephalus dux Dönitz, 1910

23. Rhipicephalus evertsi Neumann, 1897

24. Rhipicephalus exophthalmos Keirans and Walker, 1993

25. Rhipicephalus follis Dönitz, 1910

26. Rhipicephalus fulvus Neumann, 1913

27. Rhipicephalus geigyi Aeschlimann and Morel, 1965 (Boophilus)

28. Rhipicephalus gertrudae Feldman-Muhsam, 1960

29. Rhipicephalus glabroscutatum Du Toit, 1941

30. Rhipicephalus guilhoni Morel and Vassiliades, 1963

31. Rhipicephalus haemaphysaloides Supino, 1897

32. Rhipicephalus humeralis Tonelli-Rondelli, 1926

33. Rhipicephalus hurti Wilson, 1954

34. Rhipicephalus interventus Walker, Pegram and Keirans, 1995

35. Rhipicephalus jeanneli Neumann, 1913

36. Rhipicephalus kochi Dönitz, 1905

37. Rhipicephalus kohlsi (Hoogstraal and Kaiser, 1960) (Boophilus)

38. Rhipicephalus leporis Pomerantzev, 1946

39. Rhipicephalus longiceps Warburton, 1912

40. Rhipicephalus longicoxatus Neumann, 1905

41. Rhipicephalus longus Neumann, 1907. See R. pseudolongus.

42. Rhipicephalus lounsburyi Walker, 1990

43. Rhipicephalus lunulatus Neumann, 1907

44. Rhipicephalus maculatus Neumann, 1901

45. Rhipicephalus masseyi Nuttall and Warburton, 1908

46. Rhipicephalus microplus (Canestrini, 1888) (Boophilus). Some authors have listed the year 1887 for the original description of Rhipicephalus microplus (the species was described as Haemophysalis [sic] micropla), while others have used the year 1888. An inquiry to the U.S. Library of Congress has shown that Canestrini (1887) was actually published in Padova by Stabilimento Prosperini in 1888; therefore, we recognize the latter year for the description of $R$. microplus. A recent study by Labruna et al. (2009b) presents evidence that populations of $R$. microplus from Australia are not conspecific with Afrotropical and Neotropical populations, although Afrotropical and Neotropical populations are conspecific.

47. Rhipicephalus moucheti Morel, 1965

48. Rhipicephalus muehlensi Zumpt, 1943

49. Rhipicephalus muhsamae Morel and Vassiliades, 1965

50. Rhipicephalus neumanni Walker, 1990

51. Rhipicephalus nitens Neumann, 1904

52. Rhipicephalus oculatus Neumann, 1901

53. Rhipicephalus oreotragi Walker and Horak, 2000

54. Rhipicephalus pilans Schulze, 1935

55. Rhipicephalus planus Neumann, 1907

56. Rhipicephalus praetextatus Gerstäcker, 1873

57. Rhipicephalus pravus Dönitz, 1910

58. Rhipicephalus pseudolongus Santos Dias, 1953. Guglielmone et al. (2009) note that this tick is considered a synonym of $R$. longus by some authors, but no evidence has been forthcoming to support such a view; therefore, we regard $R$. pseudolongus as tentatively valid. See also $R$. cliffordi. 
59. Rhipicephalus pulchellus (Gerstäcker, 1873)

60. Rhipicephalus pumilio Schulze, 1935

61. Rhipicephalus punctatus Warburton, 1912. See R. serranoi.

62. Rhipicephalus pusillus Gil Collado, 1936

63. Rhipicephalus ramachandrai Dhanda, 1966

64. Rhipicephalus rossicus Yakimov and Kol-Yakimova, 1911

65. Rhipicephalus sanguineus (Latreille, 1806). This is the type species of the genus Rhipicephalus; it was originally named Ixodes sanguineus.

66. Rhipicephalus scalpturatus Santos Dias, 1959

67. Rhipicephalus schulzei Olenev, 1929

68. Rhipicephalus sculptus Warburton, 1912

69. Rhipicephalus senegalensis Koch, 1844

70. Rhipicephalus serranoi Santos Dias, 1950. Guglielmone et al. (2009) note that this species is considered a synonym of $R$. punctatus by some authors, but characters useful for separating the two species have been published.

71. Rhipicephalus simpsoni Nuttall, 1910

72. Rhipicephalus simus Koch, 1844

73. Rhipicephalus sulcatus Neumann, 1908

74. Rhipicephalus supertritus Neumann, 1907

75. Rhipicephalus tetracornus Kitaoka and Suzuki, 1983. Kolonin (2009) excludes R. tetracornus from his list of world Ixodidae, but the holotype nymph exists and no evidence has been proffered to support synonymization (Guglielmone et al. 2009).

76. Rhipicephalus theileri Bedford and Hewitt, 1925

77. Rhipicephalus tricuspis Dönitz, 1906

78. Rhipicephalus turanicus Pomerantzev, 1940. While most Western workers list the year 1936 for the original description of $R$. turanicus, we follow Filippova (1997), who considers 1940 to be the correct year.

79. Rhipicephalus warburtoni Walker and Horak, 2000

80. Rhipicephalus zambeziensis Walker, Norval and Corwin, 1981

81. Rhipicephalus ziemanni Neumann, 1904. See R. aurantiacus.

82. Rhipicephalus zumpti Santos Dias, 1950

\section{Nuttalliellidae}

1. Nuttalliella namaqua Bedford, 1931. This is the type species of the genus Nuttalliella.

\section{Acknowledgements}

We thank the Argentinian and South African governments, who supported part of this study within the framework of the bilateral cooperation project SA 0805. We are also grateful to the staff of the U.S. Library of Congress for their help in ascertaining the exact year of publication of some papers. This compilation was initiated under the auspices of the Integrated Consortium on Ticks and Tick-borne Diseases 3, and we appreciate the encouragement of Prof. F. Jongejan, Coordinator of the Consortium. We thank Marta Sánchez, the librarian of INTA Rafaela, for her assistance in searching the vast tick literature, along with Yago Alfonso from the Centro Argentino de Información Científica y Técnica, and Margarida Santos Silva from Portugal who collaborated with AEP. Dr. Natal'ia A. Filippova, Zoological Institute, Russian Academy of Sciences, St. Petersburg, meticulously reviewed an earlier draft of this paper. The participation of IGH in this project was supported by the National Research Foundation of South Africa. Thanks also to the Instituto Nacional de Tecnología Agropecuaria (INTA), the Asociación Cooperadora de la Estación Experimental Agropecuaria 
Rafaela de INTA, and the Consejo Nacional de Investigaciones Científicas y Técnicas (Argentina), for their support of AAG.

\section{References}

Apanaskevich, D.A. \& Horak, I.G. (2008) The genus Hyalomma. VI. Systematics of H. (Euhyalomma) truncatum and the closely related species, $H$. (E.) albiparmatum and $H$. (E.) nitidum (Acari: Ixodidae). Experimental and Applied Acarology, 44, 115-136.

Apanaskevich, D.A. \& Horak I.G. (2009) The genus Hyalomma Koch, 1844. IX. Redescription of all parasitic stages of H. (Euhyalomma) impeltatum Schulze and Schlottke, 1930 and $H$. (E.) somalicum Tonelli Rondelli, 1935 (Acari: Ixodidae). Systematic Parasitology, 73, 199-218.

Audouin, J.V. (1826) Explication sommaire des planches d'arachnides de l'Égypte et de la Syrie. In Savigny, J. 1826. Description de l'Égypte ou Recueil des Observations et des Recheches qui ont été Faites en Égypte pendant l'Expédition de l'Armée Française. Histoire Naturelle ,1 (4): 99-186. C.L.F. Panckoucke: Paris.

Barker, S.C. \& Murrell, A. (2002) Phylogeny, evolution and historical zoogeography of ticks: a review of recent progress. Experimental and Applied Acarology, 28, 55-68.

Barker, S.C. \& Murrell, A. (2008) Systematics and evolution of ticks with a list of valid genus and species names. In: Bowman A.S., Nuttall P. (Eds.) Ticks: biology, disease and control. Cambridge University Press, pp. 1-39.

Black, W.C. \& Piesman, J. (1994) Phylogeny of hard- and soft-tick taxa (Acari: Ixodida) based on mitochondrial 16S rDNA sequences. Proceedings of the National Academy of Sciences USA, 91, 10034-10038.

Camicas, J.L. \& Morel, P.C. (1977) Position systématique et classification des tiques (Acarida: Ixodida). Acarologia, 18, 410-420.

Camicas, J.L., Hervy, J.P., Adam, F. \& Morel, P.C. (1998) Les tiques du monde. Nomenclature, stades décrits, hôtes, répartition (Acarida, Ixodida). Orstom, Paris.

Canestrini, G. (1888) Intorno da alcuni Acari ed Opilonidi dell`America. Atti Società Veneto-Trentina Scienze Naturali Padova Residente Padua, 11, 100-109.

Clifford, C.M., Kohls, G.M. \& Sonenshine, D.E. (1964) The systematics of the subfamily Ornithodorinae (Acarina: Argasidae). I. The genera and subgenera. Annals of the Entomological Society of America, 57, 429-437.

Estrada-Peña, A. \& Estrada-Peña, R. (1991) Notes on Dermacentor ticks: redescription of D. marginatus with the synonymies of D. niveus and D. daghestanicus (Acari: Ixodidae). Journal of Medical Entomology, 28, 2-15.

Estrada-Peña, A., Mangold, A.J., Nava, S., Venzal, J.M., Labruna, M.B. \& Guglielmone, A.A. (2010) A review of the systematics of the tick family Argasidae (Ixodida). Acarologia, in press.

Deng, G.L., Jiang, W., Ye, R.Y. et al. (sic) (1999) The fauna of ticks and mites in the Yeerqiang river valley in Xinjiang, China. Endemic Disease Bulletin, 14, 55-57. In Chinese.

Filippova, N.A. (1961) Contribution to the taxonomy of ticks of the crenulatus group (Ixodidae, Ixodes, Pholeoixodes). Parazitologicheskiy Sbornik Zoologicheskiy Institut Akademiya Nauk SSSR, 20, 226-247. In Russian, English translation by the Translation Unit, Library Branch, Division of Research Services, National Institutes of Health, Bethesda, Maryland.

Filippova, N.A. (1964) Data on ticks of the subfamily Argasinae (Ixodoidea, Argasidae). Report II. Taxonomy of Palearctic Argasinae and diagnoses of the species of the USSR fauna for all active phases in the life cycle. Parazitologicheskiy Sbornik Zoologicheskiy Institut Akademiya Nauk SSSR, 22, 7-27. In Russian.

Filippova, N.A. (1966) Argasid ticks (Argasidae). Fauna SSSR 4 (3), Nauka, Moscow, Leningrad, 255 pp. In Russian.

Filippova, N.A. (1977) Ixodid ticks (Ixodinae). Fauna USSR New Ser. 4 (4), Nauka, Moscow, Leningrad, 316 pp. In Russian.

Filippova, N.A. (1984) Taxonomy of ticks of the family Ixodidae (Acarina: Parasitiformes) in the USSR fauna and plans for studying it. Parazitologicheskiy Sbornik Zoologicheskiy Institut Akademiya Nauk SSSR, 32: 61-78. In Russian, English translation 1796 from Medical Zoology Department, United States Naval Medical Research Unit Number Three, Cairo, Egypt.

Filippova, N.A. (1994) Classification of the subfamily Amblyomminae (Ixodidae) in connection with a reinvestigation of the chaetotaxy of the anal valves. Parazitologiya, 28, 3-12. In Russian.

Filippova, N.A. (1997) Ixodid ticks of subfamily Amblyomminae. In Fauna of Russia and neighbouring countries, 4(5), Nauka Publishing House, St. Petersburg, 436 pp. In Russian.

González-Acuña, D., Mangold, A.J., Robbins, R.G. \& Guglielmone, A.A. (2009) New host and locality records for the Ixodes auritulus Neumann, 1904 (Acari: Ixodidae) species group in northern Chile. Systematic \& Applied Acarology, 14, 47-50.

Guglielmone, A.A., Estrada-Peña, A., Keirans, J.E. \& Robbins, R.G. (2003) Ticks (Acari: Ixodida) of the Neotropical Zoogeographic Region. Special Publication of the International Consortium on Ticks and Tick-Borne Diseases-2, 
Atalanta, Houten, The Netherlands, 173 pp.

Guglielmone, A.A., Robbins, R.G., Apanaskevich, D.A., Petney, T.N., Estrada-Peña, A. \& Horak, I.G. (2009) Comments on controversial tick (Acari: Ixodida) species names and species described or resurrected from 2003 to 2008. Experimental and Applied Acarology, 48, 311-327.

Guglielmone, A.A., Nava, S., Bazán-León, E.A., Vásquez, R.A. \& Mangold, A.J. (in press) Redescription of the male and description of the female of Ixodes abrocomae Lahille, 1916 (Acari: Ixodidae). Systematic Parasitology.

Hoffmann, A. (1958) Una especie de Antricola (Acarina, Argasidae) en México. Anales de la Escuela Nacional de Ciencias Biológicas, 9, 97-107.

Hoogstraal, H. (1958) Bat ticks of the genus Argas (Ixodoidea, Argasidae). 3. The subgenus Carios, a redescription of A. (C.) vespertilionis (Latreille, 1802) and variation within an Egyptian population. Annals of the Entomological Society of America, 51, 11-26.

Hoogstraal, H. (1985) Argasid and nuttalliellid ticks as parasites and vectors. Advances in Parasitology, 24, $135-238$.

Hoogstraal, H. \& Aeschlimann, A. (1982) Tick-host specificity. Bulletin de la Société Entomologique Suisse, 55, 5-32.

Horak, I.G., Camicas, J.L. \& Keirans, J.E. (2002) The Argasidae, Ixodidae and Nuttalliellidae (Acari: Ixodida): a world list of valid tick names. Experimental and Applied Acarology, 28, 27-54.

International Commission on Zoological Nomenclature (1999) International Code of Zoological Nomenclature, $4^{\text {th }}$. Ed., The International Trust for Zoological Nomenclature 1999, $306 \mathrm{pp}$.

Keirans, J.E. (1992) Systematics of the Ixodida (Argasidae, Ixodidae, Nuttalliellidae): an overview and some problems. In: Fivaz, B., Petney, T., Horak, I. (Eds.) Tick vector biology. Medical and veterinary aspects. Springer-Verlag, pp. $1-21$.

Keirans, J.E. (2009) Order Ixodida. In Krantz G.W., Walter D.E. (Eds.) A manual of acarology $3^{\text {rd }}$ ed, Texas Tech Univ. Press, pp. 111-123.

Keirans, J.E. \& Robbins, R.G. (1999) A world checklist of genera, subgenera, and species of ticks (Acari: Ixodida) published from 1973-1997. Journal of Vector Ecology, 24, 115-129.

Klompen, J.S.H. \& Oliver, J.H. (1993) Systematic relationships in the soft ticks (Acari: Ixodida: Argasidae). Systematic Entomology, 18, 313-331.

Klompen, H., Dobson, S.J. \& Barker, S.C. (2002) A new subfamily, Bothriocrotoninae n. subfam., for the genus Bothriocroton Keirans, King \& Sharrad, 1994 status amend. (Ixodida: Ixodidae), and the synonymy of Aponomma Neumann, 1899 with Amblyomma Koch, 1844. Systematic Parasitology, 53, 101-107.

Kolonin, G.V. (2009) Fauna of ixodid ticks of the world. http://www.kolonin.org/ (August 24, 2009). Last accessed 8 Jun 2010.

Labruna, M.B. \& Venzal, J.M. (2009) Carios fonsecai sp. n. (Acari, Argasidae), a bat tick from the central-western region in Brazil. Acta Parasitologica, 54, 355-363.

Labruna, M.B., Onofrio, V.C., Beati, L., Arzua, M., Bertola, P.B. \& Barros-Battesti, D.M. (2009a) Redescription of the female, description of the male, and several new records of Amblyomma parkeri (Acari: Ixodidae), a South American tick species. Experimental and Applied Acarology, 49, 243-260.

Labruna, M.B., Naranjo, V., Mangold, A.J., Thompson, C., Estrada-Peña, A., Guglielmone, A.A., Jongejan, F. \& de la Fuente, J. (2009b) Allopatric speciation in ticks: genetic and reproductive divergence between geographic strains of Rhipicephalus (Boophilus) microplus. BMC Evolutionary Biology, 9, 46.

Lahille, F. (1916) Descripción de un nuevo ixódido chileno. Revista Chilena de Historia Natural, 20, $107-108$.

Lucas, M.H. (1844) Note sur une nouvelle espèce d'Arachnide qui appartient au genre Ixodes. Revue Zoologique de la Société Cuvierienne, 7, 71.

Lucas, M.H. (1845) Sur une nouvelle espèce d'Arachnide qui appartient au genre Ixodes, et qui vit dans le contour interne de la cavité orbitaire de Python sebae, Duméril et Bibron (Coluber sebae, Gmelin). Annales de la Société Entomologique de France, Série. 2, 3, 61-65.

McKay, I.J. (1994) Two new species of ixodid ticks closely related to Ixodes pilosus (Acari: Ixodidae). Journal of the South African Veterinary Association, 65,158.

Miller, H.C., Conrad, A.M., Barker, S.C. \& Daugherty, C.H. (2007) Distribution and phylogenetic analyses of an endangered tick, Amblyomma sphenodonti. New Zealand Journal of Zoology, 34, 97-105.

Moshaverinia, A., Shayan, P., Nabian, S. \& Rahbari, S. (2009) Genetic evidence for conspecificity between Dermacentor marginatus and Dermacentor niveus. Parasitology Research, 105, 1125-1132.

Nava, S., Estrada-Peña, A., Mangold, A.J. \& Guglielmone, A.A. (2009a) Ecology of Amblyomma neumanni (Acari: Ixodidae). Acta Tropica, 111, 226-236.

Nava, S., Guglielmone, A.A. \& Mangold, A.J. (2009b) An overview of the systematics and evolution of ticks. Frontiers in Bioscience, 14, 2857-2877.

Pomerantzev, B.I. (1950) Ixodid ticks (Ixodidae). Fauna SSSR, Paukoobraznye, 4 (2), 224 pp. In Russian.

Pospelova-Shtrom, M.V. (1969) On the Argasidae system (with description of two new subfamilies, three new tribes and one new genus). Meditsinskaya Parasitologiya i Parazitarnye Bolezni, 15, 47-58. In Russian. 
Santos Dias, J.A.T. (1956) Invalidação de algumas espécies ixodológicas originalmente determinadas em resultado de indevida rotulagem de material. Anais do Instituto de Medicina Tropical, 13, 199-208.

Santos Dias, J.A.T. (1993) Contribuição para o estudo da sistematica e taxonomia das espécies de genero Aponomma Neumann, 1899 (Acarina-Ixodoidea). Estudos, Ensaios e Documentos, (157), 1-204.

Teng, K. \& Jiang, Z. (1991) Economic insect of fauna of China. Fasc. 39 Acari: Ixodidae.Science Press, Beijing, 355 pp. In Chinese.

Voltzit, O.V. (2007) A review of Neotropical Amblyomma species (Acari: Ixodidae). Acarina, 15, 3-134.

Voltzit, O.V. \& Keirans, J.E. (2002) A review of Asian Amblyomma species (Acari, Ixodida, Ixodidae). Acarina, 10, 95136. 